\title{
The Distribution of Several Blood Group Genes in Liberia, the Ivory Coast and Upper Volta'
}

\author{
FRANK B. LIVINGSTONE, ${ }^{2}$ HENRY GERSHOWITZ, JAMES V. NEEL, \\ WOLF W. ZUELZER AND MARVIN D. SOLOMON \\ Department of Human Genetics, University of Michigan Medical School, \\ Ann Arbor, Michigan, Child Research Center of Michigan, Detroit \\ Michigan, and Department of Natural Sciences, Michigan \\ State University, East Lansing, Michigan
}

The cline for the sickle cell gene which has been demonstrated in Liberia (Livingstone, '58a) is one of the most striking in human genetics. From a high of a gene frequency of about 0.10 in northwestern Liberia, the frequency falls to essentially zero in southeastern Liberia and the adjacent Ivory Coast. During the past four years, in conjunction with the survey of the distribution of abnormal hemoglobins which led to the demonstration of this cline, we have tested 2695 West African blood samples for various red cell antigens. All of the samples were tested with ABO, $\mathrm{MN}$, and CDE anti-sera, while smaller numbers were tested for the presence of the following antigens: $A_{1}$ and $A_{2} ; c, C^{w}$, $\mathrm{D}^{\mathrm{u}}$, and $\mathrm{e} ; \mathrm{K}$ and $\mathrm{k}$; $\mathrm{Fy}^{\mathrm{a}}$; $\mathrm{Di}^{\mathrm{a}}$; $\mathrm{He}$; $\mathrm{U}$; $\mathrm{P}$; $\mathrm{Jk}^{\mathrm{a}}$; and $\mathrm{Tj}^{\mathrm{a}}$. Determinations of the serum haptoglobin types were also performed on 614 specimens. In addition to the fact that these tests are, with the exception of the ABO blood groups, the first to be reported for these antigens on the tribes of this part of West Africa and so fill a gap in existing knowledge of the blood group gene distributions, this study has provided an unusual opportunity to test for the occurrence in 12 different genetic systems of clines parallel to the sickle cell gene cline. The findings to be described are thus thought to further our understanding of the dynamics of the sickle cell gene.

\section{METHODS}

The majority of the blood samples were collected in $10 \mathrm{ml}$ "Venules" containing oxalate as an anti-coagulant, but 218 specimens in which the blood was permitted to clot were also included in the survey. The samples were kept under refrigeration un- til air-shipped in ice-packed thermos jugs to the United States. In general the blood was typed about one week to 10 days after collection, although some shipments were typed as late as three weeks after collection.

Procedures at Child Research Center. In 1955-56 the samples were tested at the Blood Grouping Laboratory of the Child Research Center of Michigan. All samples were tested once with a commercial antiserum for the presence of the following antigens: $A$ and $B ; C, D$, and $E ; M$ and $N$. Three per cent cell suspensions were used throughout. The A-B determinations were slide-typings, agitated for 5 minutes, after which the results were read grossly, but weak reactions were checked microscopically. For the MN determinations, immune rabbit sera were used. One drop of antiserum was added to a drop of the cell suspension in a test tube, and the results read with a mirror after 15 minutes at room temperature. The $\mathrm{Rh}$ determinations involved one drop of the appropriate antiserum and a like amount of cell suspension, incubated at $37^{\circ}$ for one hour, then centrifuged for one minute at $2500 \mathrm{rpm}$ in a clinical centrifuge, and the results read grossly with the aid of a concave mirror.

Procedures at Department of Human Genetics. In 1957-58 samples were tested at the Department of Human Genetics of the University of Michigan by the follow-

\footnotetext{
1 The financial support of the Rockefeller Foundation and the United States Atomic Energy Commission in these studies is gratefully acknowledged.

${ }^{2}$ National Science Foundation Postdoctoral Fellow.

${ }^{3}$ Contribution No. 101, Department of Natural Sciences, Michigan State University.
} 
ing methods. All typings were performed with washed $2 \%$ suspensions of red blood cells. The routine typing fluids were obtained from commercial sources, but the methods of testing were slightly modified from the vendor's specifications so as to standarize the procedures. All tests were set up with one drop (approx. $0.05 \mathrm{ml}$ ) of serum and one drop of red cell suspension. Centrifuge readings were taken after spinning at $2000 \mathrm{rpm}$ for approximately $5 \mathrm{sec}-$ conds. The tests for each day included positive and negative controls for each reagent, with the exception of those reagents for which one type is exceedingly rare, e.g., T ${ }^{\mathrm{a}}$-negative control, U-negative

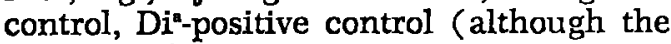
potency of the anti-Di ${ }^{*}$ serum was confirmed with a $\mathrm{Di}^{2}$-positive blood kindly supplied by Dr. M. Layrisse) and $\mathrm{C}^{\mathrm{m}}$-positive control (although the anti-C" serum was capable of detecting $\mathrm{C}^{\mathrm{w}}$ bloods in a screening of Caucasians).

In order to conserve serum all bloods were typed by means of a two stage screening procedure in which the reactions in the first stage determined the tests to be performed in the second stage, as shown below.

Bloods reacting weakly with anti-A $\mathbf{A}_{1}$ (absorbed $B$ blood) were retested in most cases with an extract of Ulex europeous (specific for $A_{2}$ and $O$ ) and in the other cases with both the Ulex extract and an extract of Dolichos biflorus (specific for $A_{1}$ ).

The original screenings for $M$ and $N$ were performed using commercially available rabbit immune sera. In general all the reactions for $M$ and $N$ were quite weak even though the control bloods reacted strongly. The difference in intensity of reaction between the African and control bloods is probably attributable to the greater age of the former. Bloods giving doubtful reactions were re-examined with two rabbit anti-M and a potent rabbit anti-
$\mathbf{N}$ serum (these sera were made in this laboratory), and in some cases with a human anti-M.

Bloods reacting atypically with the routine $\mathrm{Rh}$ typing fluids were retested with several sera specific for the antigen involved, each serum being obtained from a different commercial laboratory.

The Coombs serum used in screening for Kell and Duffy was composed of a mixture of two rabbit anti-human sera. This serum mixture gave good reactions with Kell and Duffy positive controls set up daily, even though there was almost universal failure to detect evidence for Kell or Duffy sensitization among the African bloods. Unfortunately it was not feasible to attempt large scale absorption experiments to determine the true antigenic composition of these bloods.

\section{RESULTS}

The complete results by phenotype are given in tables 1-3. The results are presented separately for the specimens tested in 1955-56 at the Child Research Center, and those tested in 1957-58 at the Department of Human Genetics. For the most part the results are shown by tribe. However, due to the small numbers tested in the Ivory Coast and Upper Volta and to the multiplicity of small tribes in these regions, none of the tribal samples from these regions, with the exception of the Mossi and the Kru, is greater than 20; so that we have combined the samples from these regions into larger groupings. These groupings undoubtedly contain populations which differ significantly in the frequency of some blood group genes. But it should be noted that the breeding unit in this part of West Africa is frequently even smaller than the tribe; so that many of our tribal groups also contain several breeding "isolates," which may well differ significantly in the frequency of some blood group genes.

\begin{tabular}{|c|c|c|}
\hline $\begin{array}{l}\text { First stage } \\
\text { reagent }\end{array}$ & $\begin{array}{c}\text { First stage } \\
\text { reaction }\end{array}$ & $\begin{array}{l}\text { Then tested with } \\
\text { second stage reagent }\end{array}$ \\
\hline $\begin{array}{l}\mathbf{A} \\
\mathbf{A} \\
\text { Saline } \mathbf{C} \\
\text { Saline } \mathbf{D} \\
\text { Saline } \mathbf{E} \\
\mathbf{K}\end{array}$ & $\begin{array}{l}\frac{+}{+} \\
\frac{+}{+} \\
+\end{array}$ & $\begin{array}{l}\text { Anti-A (absorbed B blood) } \\
\text { Rabbit anti-A (titer 1/800) } \\
\text { Anti-Cw, anti-c } \\
\text { Incomplete anti-D by Coombs test } \\
\text { Anti-e (negatives retested with trypsinized blood) } \\
\text { Anti-k }\end{array}$ \\
\hline
\end{tabular}




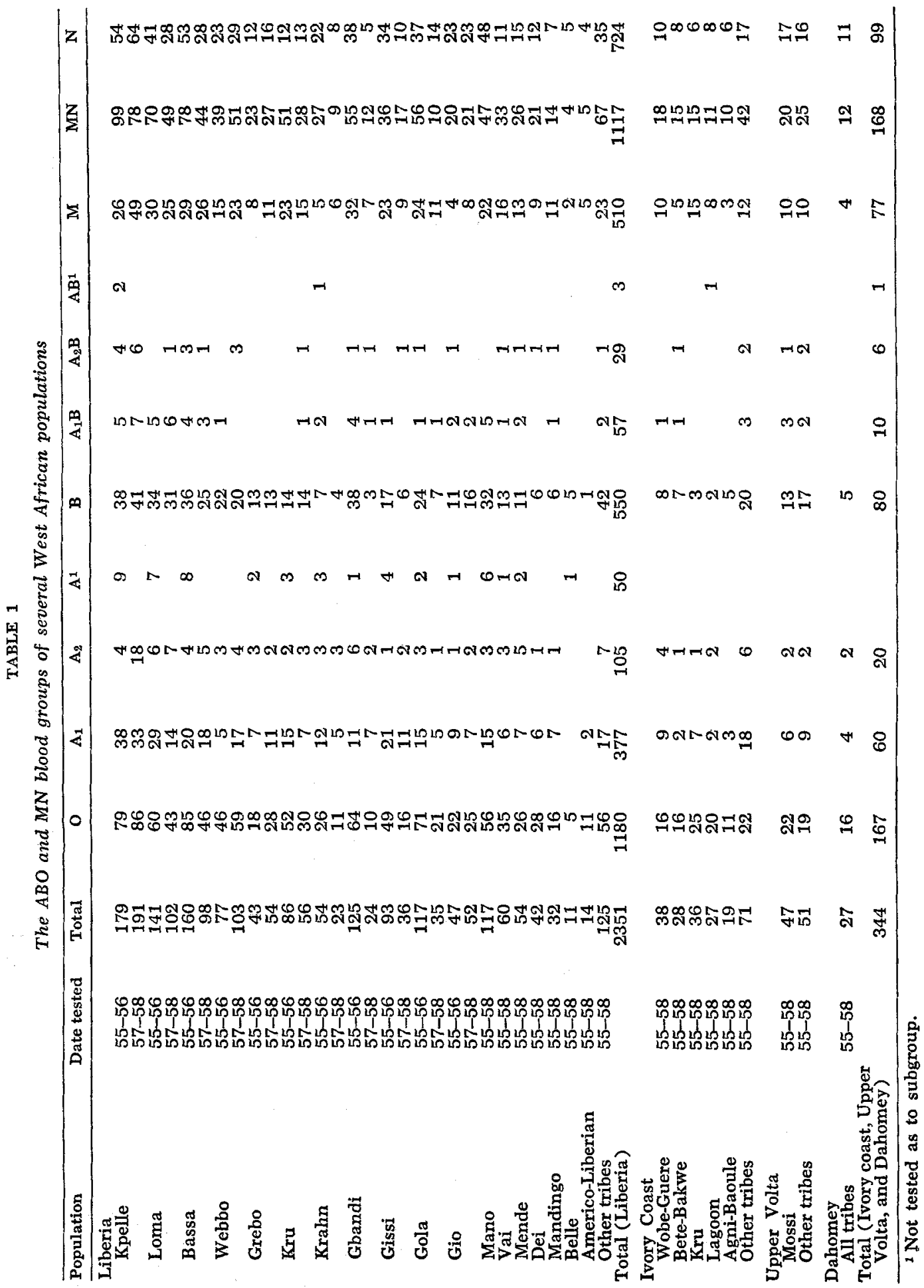




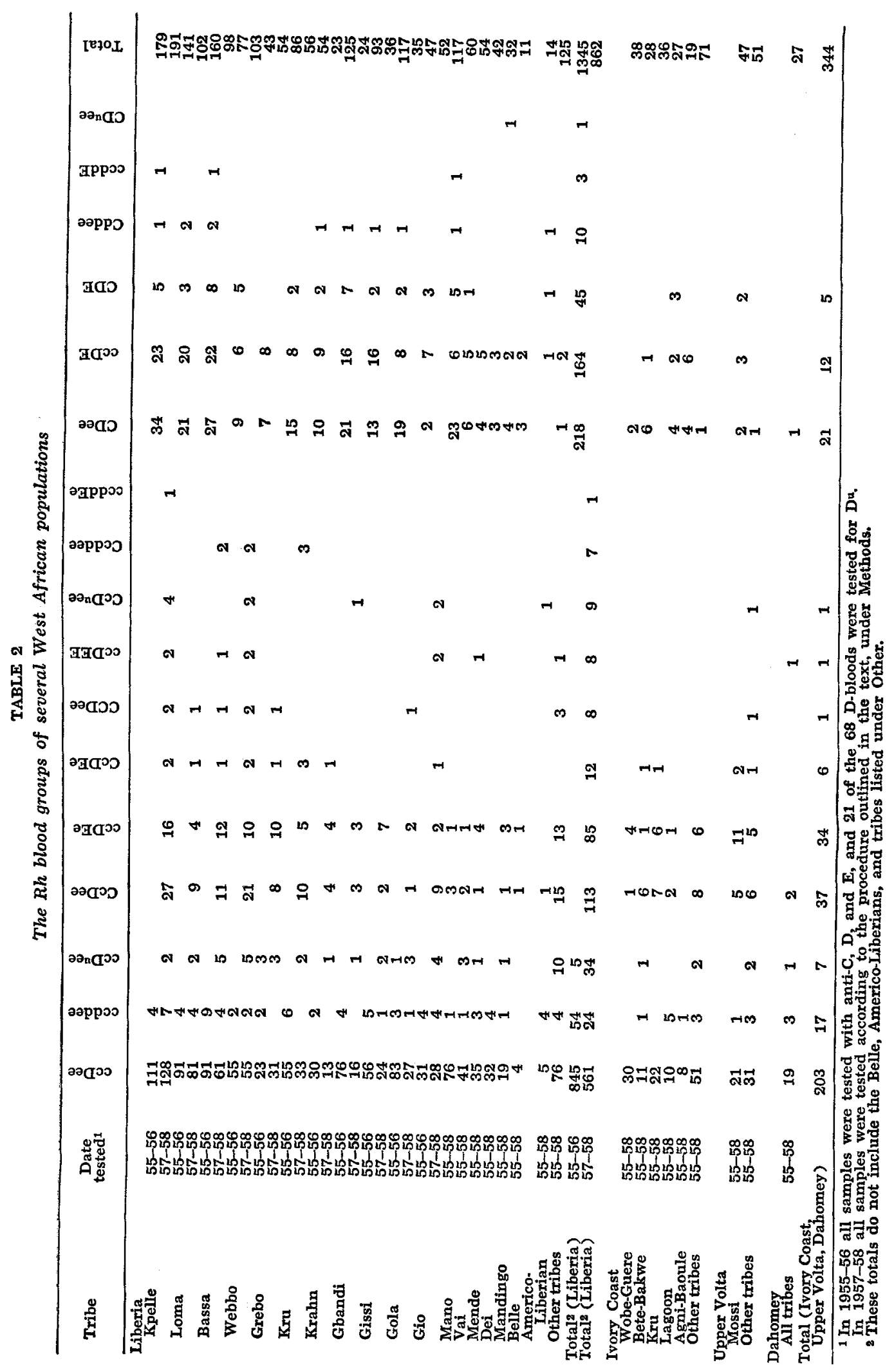




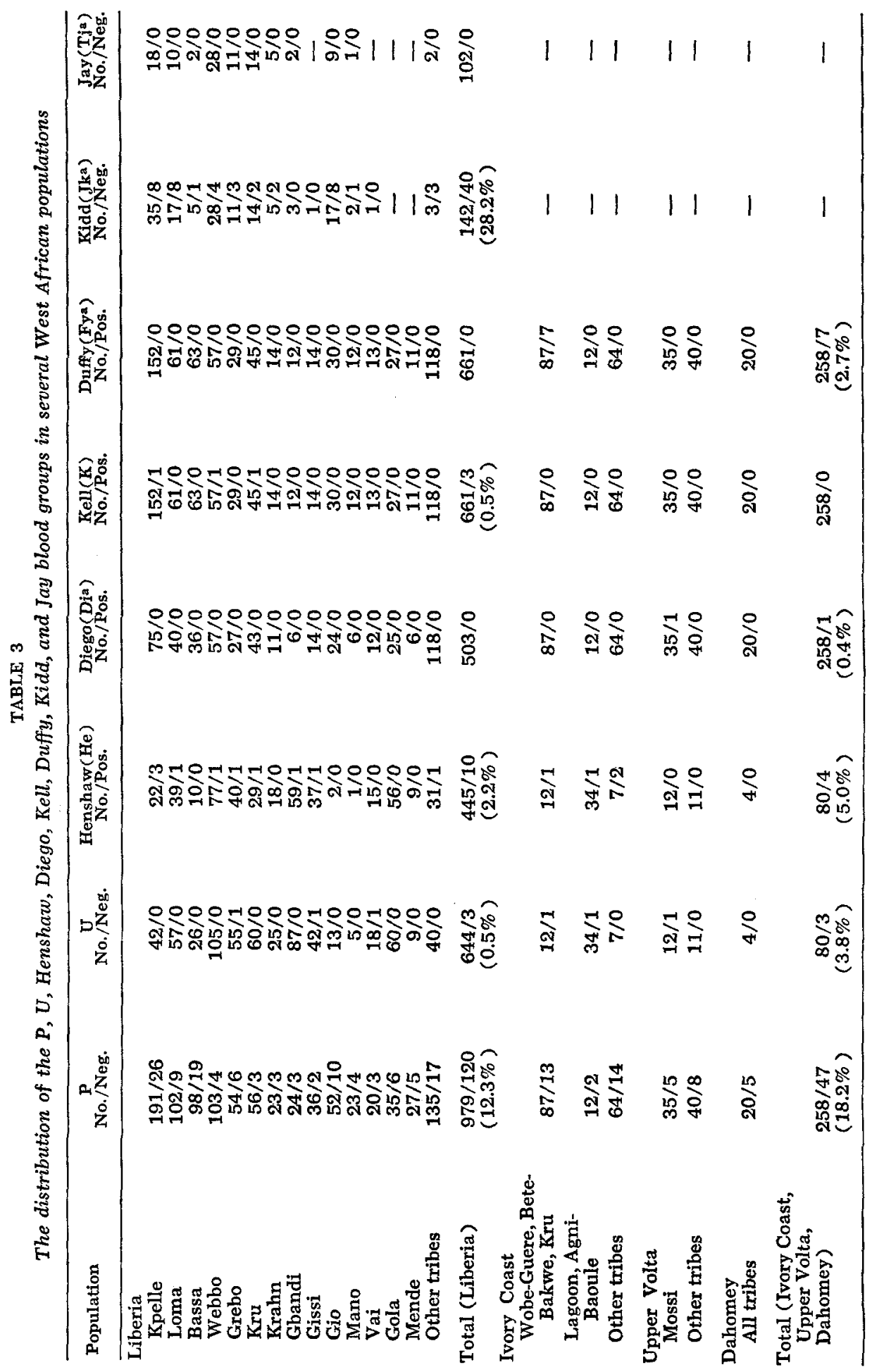


The gene frequencies were calculated by the methods outlined in Mourant ('54). The numbers of tests performed differ for the various blood group systems, primarily because of the rarity of certain anti-sera. In addition, with respect to two blood group systems ( $A B O$ and $R h$ ), only a portion of the samples were tested for some of the subgroups. For example, not all of the $D$-negative samples were tested for $D^{u}$; to obtain the frequency of the $D^{u}$ gene we have applied the percentage of $D$-negative bloods which were found to be $D^{u}$ to the total number of $\mathrm{D}$-negative bloods.

The gene frequency calculations are also complicated in several cases by significant differences between the two testing periods in the frequencies of the blood group phenotypes. Aside from the fact that at times different populations were sampled, these differences are most likely due to a combination of the following three reasons: (1) condition of the blood samples on arrival at the laboratory, (2) variability in the strength of the anti-sera used, and (3) differences in the testing procedures of the two laboratories. These inconsistencies only affect some of our calculations and will be treated in greater detail in our calculations for the various blood group systems. We will begin with the $A B O$ system.

The $A B O$ system. A $x^{2}$ test indicates that the frequencies of the $\mathrm{ABO}$ blood group genes vary significantly among the tribes of Liberia ( $x^{2}=57.939,15$ d.f., $\mathrm{P}<0.001)$. There are no significant differences between the samples for the various tribes in 1955-56 and in 1957-58, and in addition the results are not significantly different from Julien's ('37) data for the Mano, Gio, Kpelle, Loma, Kru, Bassa, Mende, and Vai tribes. Thus, although there is great variability among the tribes, their frequencies appear to have been rather constant for the last 25 years. In contrast to the $\mathrm{ABO}$ blood group genes, the frequencies of the subgroups of $A$ are not significantly different among the tribes when the proportion of $A$ which is $A_{2}$ is tested by $x^{2}$ for our 1955-56 samples $\left(x^{2}=16.234,15\right.$ d.f., $0.3<\mathrm{P}<0.5$, or for our 1957-58 sample $\left(x^{2}=7.516,13\right.$ d.f., $\left.0.75<P<0.90\right)$. Hence, although the frequency of blood group A may vary considerably among the tribes, the proportion of $A$ which is $A_{2}$ does not vary significantly. However, the rela- tive proportion of $A_{2}$ which we found in $1957-58$ is significantly greater than that found in 1955-56 ( $x^{2}=7.558,1$ d.f., $0.005<\mathrm{P}<0.010)$. This difference may be due in part to differences in the $A_{1}$ antisera which were used by the two laboratories, and in part to differences in the testing procedures of the two laboratories, especially with reference to the use of a Ulex preparation in one laboratory. In 1955-56 at the Child Research Center Laboratory all samples were tested once, but in 1957-58 at the Department of $\mathrm{Hu}-$ man Genetics Laboratory almost all weak positives were retested and some were retested several times. In addition, for many blood group antigens two or more anti-sera were used at the Department of Human Genetics Laboratory and the weakly reacting samples tested simultaneously with them. Because of the retesting of all weak positives, it would be expected that the number of positives for any test would decrease from our 1955-56 survey to our 1957-58 survey. Since this actually occurred for many of the blood group systems, this difference in testing procedure seems to account for the significant differences in the frequency of various antigens which were found by the two laboratories. In $1955-56,83 \%$ of the A-type bloods which were tested for $A_{1}$ were positive, while in $1957-58,73 \%$ were positive. In 1955-56 the samples were tested once with a human anti- $A_{1}$ (absorbed B blood), but in 1957-58 weak positives for $A_{1}$ were retested with a Ulex extract which gives a strong reaction with $A_{2}$ and fails to react with $A_{1}$. Thus, in many cases (55\%) samples which were weakly positive with anti- $A_{1}$ reacted strongly with the Ulex extract and hence were treated as $A_{2}$. Because of this additional testing it can be seen that a decrease in the frequency of $A_{1}$ would be expected in 195758. The $A B O$ gene frequencies for the tribes listed in table 1 are shown in table 6 . Since the tribes do not differ significantly in the proportion of the A gene which is $A_{2}$ we have not calculated the $A_{1}$ and $A_{2}$ gene frequencies separately, but it can be stated on the basis of the 1957-58 results that about $27 \%$ of the $A$ genes are $\mathrm{A}_{2}$.

The MN system. For the MN system there were no significant differences be- 
tween the sample for the particular tribe in 1955-56 and that in 1957-58, and in only two tribal samples, the Kpelle in 1957-58 and the Gola in 1957-58, were the phenotypic frequencies significantly different from those expected in a HardyWeinberg equilibrium, due to an apparent excess of homozygotes. The Kpelle and Gola are among the largest tribes of Liberia and contain several breeding isolates. This apparent departure from Hardy-Weinberg equilibrium in the two samples may be due to the statistical phenomenon first noted by Wahlund ('28)."

A further possible illustration of the operation of this principle is to be observed when the total MN determinations for Liberia in 1957-58 are compared with the expected values in a Hardy-Weinberg equilibrium. Here again there is a very significant excess of homozygotes $\left(x^{2}=\right.$ 8.062, 1 d.f., $0.001<\mathrm{P}<0.005$ ), and for the total of both 1955-56 and 1957-58 there is also an excess of homozygotes which is significant $\left(x^{2}=5.037,1\right.$ d.f., $0.010<\mathrm{P}<0.025$ ). Since the tribes of Liberia differ significantly in their $M$ gene frequencies $\left(x^{2}=33.759,15\right.$ d.f., 0.001 $<\mathrm{P}<0.005)$, as in the Kpelle and Gola example cited earlier, these apparent excesses of homozygotes appear to be due to Wahlund's principle. If the expected values of the three phenotypes are adjusted according to Wahlund's formula, then the observed values are not significantly different from the expected $\left(x^{2}=2.935,1\right.$ d.f., $0.05<\mathrm{P}<0.10$ ). When it is remembered that the tribal frequencies are most likely means of several isolates and hence that the variance of the $M$ gene frequency among the tribes of Liberia is most likely less than its variance among the breeding isolates of Liberia, then the data seem to be an even better fit to this formula, since we have corrected the zygotic proportions by the lesser value, the variance of the $M$ gene among the tribes.

In this connection it should be noted that a deficiency of heterozygotes for MN has been a rather common finding in Africa. Moullec, Linhard, and Sutton ('52) reported a deficiency of heterozygotes for MN from the tribes centered around Dakar, and proposed a silent $\mathrm{M}_{2}$ gene in appreciable frequencies as an explanation. Shapiro and Vandepitte ('55) have also reported a deficiency of MN heterozygotes from the Congo. Thus, it appears that surveys in Africa which combine many tribes, which in turn contain many isolates, are very likely to find a deficiency of $\mathrm{MN}$ heterozygotes, depending, of course, on the variability of the $M$ gene among the isolates sampled. Since many tribes in Africa contain more than one breeding isolate, this could also happen on surveys which recorded their results by tribe. The fact that this occurs frequently in Africa and not in Europe is due to the greater variability between isolates in Africa, which is a result of the smaller size of the isolates and the more limited gene flow between them.

The Rh system. In contrast to the $\mathrm{ABO}$ and $\mathrm{MN}$ systems, the $\mathrm{Rh}$ phenotypic frequencies do not vary significantly among the tribes of Liberia ( $x^{2}=76.857,60$ d.f., $0.05<\mathrm{P}<0.10)$. For this test we have combined our data for 16 tribes into the phenotypes, cDe, $\mathrm{CDe}, \mathrm{CDE}, \mathrm{CDE}$, and all D-negative (including $D^{\mathfrak{w}}$ ), irrespective of $\mathrm{C}$ and $\mathrm{E}$ reactions. Although the tribes do not differ significantly, we have calculated the chromosome frequencies separately for each tribe, and these together with the chromosome frequencies of the tribes of the Ivory Coast and Upper Volta are shown in table 6 . For the calculation of the tribal frequencies, we have combined the data

${ }^{4}$ If a population is subdivided into $K$ breeding isolates of approximately equal size, then where $\mathrm{q}_{1}$ is the frequency of the $M$ gene in the ith breeding isolate and $q$ is the frequency of the $M$ gene for the total population, the following relations hold:

$$
\overline{\mathrm{q}}=\frac{\Sigma \mathrm{q}_{\mathrm{i}}}{\mathrm{K}} \quad \sigma \mathrm{q}^{2}=\frac{\Sigma\left(\mathrm{q}_{\mathrm{i}}-\overline{\mathrm{q}}\right)^{2}}{\mathrm{~K}}=\frac{\Sigma \mathrm{q}_{\mathrm{i}}{ }^{2}}{\mathrm{~K}}-\overline{\mathrm{q}}^{2}
$$

And if each breeding isolate is large enough so that the zygotic proportions will be:

$$
q_{i}{ }^{2} ; 2 q_{i}\left(1-q_{i}\right) ;(1-q)^{2}
$$

Then the zygotic proportions for the total population will be:

$$
\begin{aligned}
& \mathrm{MM}: \frac{\Sigma \mathrm{q}_{i}{ }^{2}}{\bar{K}}=\bar{q}^{2}+\sigma \mathrm{q}^{2} \\
& \mathrm{MN}: \frac{2 \Sigma \mathrm{q}_{\mathrm{i}}\left(1-\mathrm{q}_{\mathrm{i}}\right)}{\mathrm{K}}=2 \mathrm{q}(1-\overline{\mathrm{q}})-2 \sigma \mathrm{q}^{2} \\
& \mathrm{NN}: \frac{\Sigma\left(1-\mathrm{q}_{\mathrm{i}}\right)^{2}}{\mathrm{~K}}=(1-\overline{\mathrm{q}})^{2}+\sigma \mathrm{q}^{2}
\end{aligned}
$$

Thus it can be seen that for the total population there will be an increase in homozygotes which will be proportional to the variability of the gene frequency among the subdivisions. 
for 1955-56 and that for $1957-58$, but it should be noted that the phenotype frequencies of the total sample for 1955-56 differ significantly from those of the 195758 sample. In the 1955-56 sample there is a significant excess of the CDE phenotype and smaller excesses of the CDe and cDE phenotoypes. As for the $A_{1}$ antigen of the $A B O$ system, these excesses of positives for the $\mathrm{C}$ and $\mathrm{E}$ antigens seem to be due to differences in the testing procedures of the two laboratories. There were many weak positives for these antigens and these were retested in 1957-58. As a result many were found to be negative. Since the phenotypic frequencies found in 1955-56 are significantly different from those found in 1957-58, we have calculated the chromosome frequencies separately for the two sets of data, and the results are shown in table 4 . In 1955-56 most of the D-negative bloods were not tested for $D^{u}$, so that the relative proportion of D-negative bloods which are positive for $D^{\mathfrak{u}}$ is based on a very small sample. Aside from this difference it can be seen that the two samples from Liberia agree quite closely. All the C-positive samples in 1957-58 were tested for $\mathrm{C}^{\mathrm{w}}$; no positives were found in the survey. This antigen is known to be rare in Africa, but this finding of $0 \%$ is the lowest to be reported (summary in Mourant, '54).

The Fy system. Only $7 \mathrm{Fy}^{\mathrm{a}}$-positives were found in the entire survey, and these were all in one shipment. Since this shipment arrived at the laboratory in a poorer condition than most shipments and was tested much later than most, we would suspect these to be false positives, inasmuch as 200 clotted blood samples in especially good condition, and several hundred

TABLE 4

The Rh chromosome frequencies of the 1955-56 and 1957-58 shipments from Liberia (excluding the Belle, Americo-Liberians and tribes listed under Other)

\begin{tabular}{lcc}
\hline & $1955-1956$ & $1957-1958$ \\
\hline Number tested & 1,345 & 862 \\
cDe & 0.6039 & 0.5853 \\
CDe & 0.0882 & 0.0688 \\
cDE & 0.0765 & 0.0637 \\
cde & 0.1810 & 0.1661 \\
Cde & 0.0189 & 0.0223 \\
cdE & 0.0053 & 0.0024 \\
cDue & 0.0263 & 0.0921 \\
\hline
\end{tabular}

oxalated samples from neighboring and related tribes in Liberia were all negative. A low frequency of the $\mathrm{Fy}^{\mathrm{a}}$ gene is characteristic of African populations, but this finding of essentially zero seems to be confined to West Africa, where Race and Sanger ('58) have also reported $0 \%$ among a small sample (37) of Nigerians and Ghanaians. Shapiro and Vandepitte ('55) report $8 \%$ positives for the $\mathrm{Fy}^{\mathrm{a}}$ antigen in the Congo, and Zoutendyk ('55) reports $28 \%$ among the Hottentots and 16\% among the Bushmen in South Africa. Gershowitz (unpublished) has observed $3.8 \% \mathrm{Fy}^{\mathrm{a}}$-positives among 157 natives of Kenya. There is thus the suggestion of a lower frequency of $\mathrm{Fy}^{\mathrm{a}}$-positives in West than in East or South Africa, but no evidence at present for a cline within West Africa. There is some disagreement as to the frequency of $\mathrm{Fy}^{\mathrm{a}}$-positives among the American Negro since Miller et al. ('51) report $26 \%$ positives among a sample of 200 New York Negroes, while Sanger, Race, and Jack ('55) report $10.4 \%$ for a sample of 125 of the same population. In this laboratory, $20.3 \%$ of a sample of 206 American Negroes were $\mathrm{Fy}^{\mathrm{a}}$-positive (Gershowitz, unpublished). In any case, however, a very low frequency would be expected among Africans in view of the 65\% Fy-positives among Caucasians and the fact that the American Negro gene pool appears to have about $25 \%$ Caucasian genes (Glass, '55).

The $T j^{a}$ and $D i^{a}$ systems. No $\mathrm{Tj}^{\mathrm{a}}$-negatives were found on the survey, but in view of the rarity of the $T j^{b}$ gene and the size of our sample, none would be expected. The results for the Diego system have been discussed in another publication (Gershowitz, '59).

The $K, U$, and He systems. Our results for the Kell, $U$ and Henshaw systems are similar to those of other investigations in Africa. No Kell positives were found in the Ivory Coast specimens and the frequency of Kell positives was very low in Liberia $(0.5 \%)$. The frequency of U-negatives was also quite low in Liberia $(0.5 \%)$, but this frequency rose to $3.8 \%$ in the Ivory Coast. A similar cline in the frequency of the Henshaw antigen also seems to be present with $0.5 \%$ Henshaw positive in Liberia, $5.0 \%$ positive in the Ivory Coast, and $4.3 \%$ in Ghana to the east of the Ivory 
TABLE 5

The frequencies of the $\mathrm{P}$ and $J k^{a}$ blood groups in the shipments from Liberia, in relation to time of shipment

\begin{tabular}{|c|c|c|c|c|c|c|}
\hline \multirow{2}{*}{$\begin{array}{l}\text { Date and } \\
\text { method of } \\
\text { shipment }\end{array}$} & \multicolumn{3}{|c|}{ P blood group } & \multicolumn{3}{|c|}{$\mathrm{Jk}^{\mathrm{a}}$ blood group } \\
\hline & $\begin{array}{c}\text { No. } \\
\text { tested }\end{array}$ & $\begin{array}{l}\text { No. } \\
\text { neg. }\end{array}$ & $\begin{array}{c}\text { Freq. } \\
\text { neg. }\end{array}$ & $\begin{array}{c}\text { No. } \\
\text { tested }\end{array}$ & $\begin{array}{l}\text { No. } \\
\text { neg. }\end{array}$ & $\begin{array}{l}\text { Freq. } \\
\text { neg. }\end{array}$ \\
\hline $\begin{array}{l}20 \text { Oct. } 57 \text { (Oxalated blood) } \\
31 \text { Oct. } 57 \text { (Oxalated blood) } \\
25 \text { Nov. } 57 \text { (Oxalated blood) } \\
29 \text { Jan. } 58 \text { (Oxalated blood) } \\
15 \text { Feb. } 58 \text { (Clotted blood) } \\
10 \text { May } 58 \text { (Oxalated blood) } \\
5 \text { Jun. } 58 \text { (Oxalated blood) } \\
12 \text { Jun. } 58 \text { (Oxalated blood) } \\
30 \text { Jun. } 58 \text { (Oxalated blood) } \\
4 \text { Aug. } 58 \text { (Oxalated blood) } \\
25 \text { Aug. } 58 \text { (Oxalated blood) }\end{array}$ & $\begin{array}{r}79 \\
138 \\
42 \\
40 \\
218 \\
158 \\
76 \\
150 \\
82 \\
54 \\
73\end{array}$ & $\begin{array}{r}11 \\
2 \\
1 \\
1 \\
24 \\
41 \\
16 \\
22 \\
8 \\
5 \\
9\end{array}$ & $\begin{array}{l}0.139 \\
0.015 \\
0.024 \\
0.025 \\
0.110 \\
0.260 \\
0.211 \\
0.147 \\
0.098 \\
0.093 \\
0.123\end{array}$ & $\begin{array}{l}60 \\
42 \\
40\end{array}$ & $\begin{array}{r}12 \\
24 \\
4\end{array}$ & $\begin{array}{l}0.200 \\
0.571 \\
0.100\end{array}$ \\
\hline Totals ${ }^{1}$ & 1,110 & 140 & 0.126 & 142 & 40 & 0.282 \\
\hline
\end{tabular}

1 The total for the $P$ blood group does not agree with that on table 3 because the results for several pregnant women and individuals known to be related are included here but not on table 3 .

Coast (Mourant, '54). While in Ghana and Nigeria the Henshaw gene seems to be associated only with $\mathbf{N}$ (Mourant, '54), we have found Henshaw positives associated with $\mathrm{M}$ as well as $\mathbf{N}$, as has Nijenhuis ('55) in the Congo and Pollitzer ('58) in the United States. Our positive Henshaw reactions were strong ( ++++$)$ and associated with the MN blood groups as follows:

\begin{tabular}{lcccc}
\hline & MM & MN & NN \\
\hline Henshaw positives & 3 & 6 & 5 \\
\hline
\end{tabular}

The $P$ and $J k^{a}$ systems. The $\mathrm{P}$ and $\mathrm{Jk}^{\mathrm{a}}$ blood group antigens have more intermediate frequencies among the tribes of Liberia than the other less well-known blood groups, and, as perhaps would be expected from the greater sampling variance at intermediate frequencies, the tribal frequencies seem to show greater variability. However, this increased variability for these blood groups may be due in part to other factors. For both blood groups there is a greater variability in the frequency of positives in the different shipments than was observed for the other groups, raising the possibility of technical difficulties. The frequencies of the $P$ and $\mathrm{Jk}^{\mathrm{a}}$ antigens in each shipment for which they were tested are shown in table 5 . For the $\mathrm{P}$ blood group the variability among the shipments in the frequency of P-negatives seems to be due in part to variability in the strength of the reagent, and at one time during our survey (May, 1958) the reagent became noticeably so much weaker that it was discarded. Nonetheless, all the variability in the frequency of P-negatives is not due to differences in the strength of the reagent. With a new reagent in June, $1958,21 \%$ negatives was found which compares to the $26 \%$ negatives found in May with the weaker reagent. On the other hand, for the $\mathrm{Jk}^{\mathrm{a}}$ blood group the same reagent was used for all tests, and the differences in the frequency of $\mathrm{Jk}^{\mathrm{a}}$-negatives among the shipments do not seem to be attributable at all to a weakening of the anti-sera used. Most of our $\mathrm{Jk}^{\mathrm{a}}$ reactions were rather weak, and our data indicate that this antigen may be more subject to deterioration. However, the shipment with a high proportion of $\mathrm{Jk}^{\mathrm{a}}$-negatives (25 Nov., 1957) did not appear to be in any worse condition than the others, nor was it tested any later after collection.

If we take the observed frequencies of the $P$ and $\mathrm{Jk}^{\mathrm{a}}$ antigens at face value, ignoring the possibility of technical error, our results differ from what has usually been reported on African and African-derived populations. In previous studies on West Africans from Nigeria and Ghana and American Negroes, the frequency of individuals negative for $\mathrm{Jk}^{\mathrm{a}}$ has been less than 7\% (summary in Mourant, '54). Our finding of $28 \% \mathrm{Jk}^{\mathrm{a}}$-negatives is thus much higher than those of other studies. With respect to the $\mathrm{P}$ system, $13.5 \%$ of the 1237 natives we tested in this respect were $P$. 
negative. Limited studies on the natives of Nigeria and Ghana, as well as American Negroes, have shown values of less than $7 \%$ P-negatives (summary in Mourant, '54), but Moullec et al. ('52) found a $12 \%$ value in 781 natives from tribes in the vicinity of Dakar. In addition, Shapiro ('51, '53) found 13.2 and $8.0 \%$ $\mathrm{P}$-negatives in two studies of South African Bantu, and Goldsmith (quoted in Mourant, '54) found $27.9 \%$ P-negatives in the Somali, although the Somali are a Cushitic tribe in Ethiopia and Somaliland and thus not strictly "Negro." In any case it may well be that there is considerable variability in the frequency of these blood groups in different parts of Africa, which as for many other blood groups limits the usefulness of the term "African" or "Negro" in reference to the frequencies of these blood groups. For the $\mathrm{Jk}^{\mathrm{a}}$ group, then, our limited results suggest a higher frequency of negative reactors in the tribes of Liberia and the Ivory Coast than in the tribes of surrounding regions, but the results are insufficient to establish the occurrence of a cline if such exists. With respect to the $P$ antigen the differences from the values reported for surrounding regions are less striking, and, in view of the possible technical problems mentioned above, are not thought worthy of further discussion.

\section{DISCUSSIONS}

Before we attempt to discuss the anthropological and genetic significance of our findings, we would like to point out certain implications of the significant differences in our survey which have been associated with different testing procedures. We think the possibility that such differences may occur, or in other words that there is a degree of uncertainty in blood typing which must be borne in mind in the interpretation of blood group gene frequencies, especially when "old" blood is used, has not been properly emphasized in most publications. Our findings would seem to imply that in a program in which blood specimens which are one week or more old are subjected to a single test for a particular antigen, a significant number of specimens will exhibit weak positive reactions which are not duplicated on a retest. The differences in the two laboratories which were noted in this study stem almost entirely from the availability, in one laboratory, of personnel for retesting procedures. It should also be noted that many of the "significant" differences are actually relatively small, and emerge as significant only because of the size of the samples concerned. It may be that oxalation of our samples was responsible for these false positives, which would limit the implications of our findings. In this connection it should be noted that Osborne ('58) has presented evidence that differences in technique between laboratories may be a significant factor in the percentage of positive reactions even when fresh, clotted blood is used. It is impossible to estimate to what extent routine blood grouping techniques, which are quite universally employed in survey studies, have led to overestimates of antigen frequencies in other investigations. Be that as it may, in the present instance we have combined the results of the two series, although recognizing that in consequence the antigen and gene frequencies resulting thereby may for some systems be slightly higher than the true values.

In any case the results of our survey accord in many general features with the usual findings for the major blood group systems in West Africa and in other parts of the world. For West Africa our results are similar to the findings in those regions thus far studied, namely Ghana and Nigeria (summary in Mourant, '54), Portuguese Guinea (Mourant, '58; Trincao, Franco, Gouveia and Parreira, '53), and the Senegal (Moullec, Linhard and Sutton, '52). Each of these studies shows that there is significant variability in the $\mathrm{ABO}$ and MN systems within the respective countries, but there do not appear to be significant clines in the frequencies of these genes. Among the tribes of Liberia there are some who possess frequencies similar to some tribes in Ghana, others who are similar to tribes in Portuguese Guinea, and still others similar to tribes in the Senegal; and these similarities do not appear to be related to linguistic, ethnic, or cultural similarities. Thus, the variability in the $A B O, M N$, and $R h$ systems appears to be for the most part random. On the other hand, although data on the $\mathrm{U}, \mathrm{K}, \mathrm{He}, \mathrm{P}$ and $\mathrm{Jk}^{\mathrm{a}}$ systems are less extensive, there may well be in West 
Africa, centering in the vicinity of Liberia, significant clines in the frequency of some of the responsible genes, namely, $\mathrm{He}$ and $\mathrm{U}$, and - somewhat more indefinite- $\mathrm{Jk}^{\mathrm{a}}$.

Because of the presence in Liberia and the Ivory Coast of a significant cline in the frequency of the sickle cell gene, a gene with a marked selective advantage in the heterozygous state (Raper, '56; Vandepitte and DeLaisse, '57; Lambotte-Legrand, '58), our data present an unusual opportunity to compare this cline with the frequencies of the blood group genes. We will restrict the detailed comparison to the $\mathrm{ABO}, \mathrm{Rh}$, and MN systems - the major systems-for which we have the more complete data. In table 6 we have arranged the tribes by linguistic affiliation and, as well as possible, in descending frequency of the sickle cell gene. In table 6 the sickle cell gene can be seen to have a very significant cline among the tribes of Liberia, while none of the other blood group systems shows a similar cline. When the tribes are grouped by linguistic affiliation, which is used in table 6 to indicate ethnic relation, there does not seem to be any striking overall association between the frequencies of the blood group genes and linguistic affiliation. To be sure, closely related tribes such as the Mano and Gio do show marked similarities in the frequency of some blood group genes; and the Mandingo and Vai, whose languages are closely related, do have in common a much higher frequency of the $M$ gene than is usual in Liberia. However, there seem to be as many differences between closely related tribes as there are similarities. Thus, the variability in these blood group systems seems to be for the most part random when examined in this manner. One of us (Livingstone, '58a) has postulated that the distribution of the sickle cell gene in Liberia is due to the recent advance of the gene by a relatively small amount of gene flow between stable populations followed by a rapid increase in gene frequency due to intense selective pressures. The absence of parallel clines in the major blood group systems seems to imply that these other genes were already present in near equilibrium frequencies prior to this gene flow.

There is also a rather striking cline in the frequency of the sickle cell gene in Portuguese Guinea, where the West Atlantic- speaking tribes on the seacoast between the Cacheu and Casamance Rivers have very low frequencies of the sickle cell gene with the frequency of this gene increasing as one proceeds inland from this stretch of coastline. As is the case in Liberia, the tribes with very low frequencies of the sickle cell gene in Portuguese Guinea seem to be relict populations of the primitive inhabitants of West Africa who were forced back into this area by later migrations. In table 7 are shown the available data on the frequencies of the sickle cell gene and the $\mathrm{ABO}$ and $\mathrm{Rh}$ blood group genes in the tribes of Portuguese Guinea the tribes being arranged in ascending frequencies of the sickle cell gene. As in Liberia there seems to be little or no association between the frequencies of the sickle cell gene and those of the blood group genes. Thus, once again the conclusion seems to be that the variability in the frequency of the blood group genes is not associated with the cline in the sickle cell gene or with common ancestry.

A third study of this nature, that by Hiernaux ('56) of the populations of Ruanda-Urundi and the eastern Belgian Congo, involving the $\mathrm{ABO}, \mathrm{MN}, \mathrm{Rh}$, and sickling systems, also seems to point in general to a similar conclusion, although there is one exception to be discussed below. In table 8 the populations of Hiernaux's study are arranged in a similar manner to the ordering of the populations of Liberia in table 6 , but we have added the mean altitude of the tribe's habitat in table 8 , since this factor seems to affect the distribution of the sickle cell gene very strikingly. The correlation between altitude and the frequency of the sickle cell gene $(r=0.73)$ is significant at the $1 \%$ level. It can be seen that all tribes which are above 1500 meters in altitude have very low frequencies of the sickle cell gene, which is presumably related to the fact that there is little falciparum malaria at these heights. However, the tribes who inhabit the lower altitudes do not invariably have high frequencies of the sickle cell gene. Thus, other factors, in addition to selection with respect to falciparum malaria, seem to be involved in determining the distribution of the sickle cell gene in this part of Africa, as is the case in West Africa (Livingstone, '58b). In Ruanda- 
FRANK B, LIVINGSTONE AND OTHERS

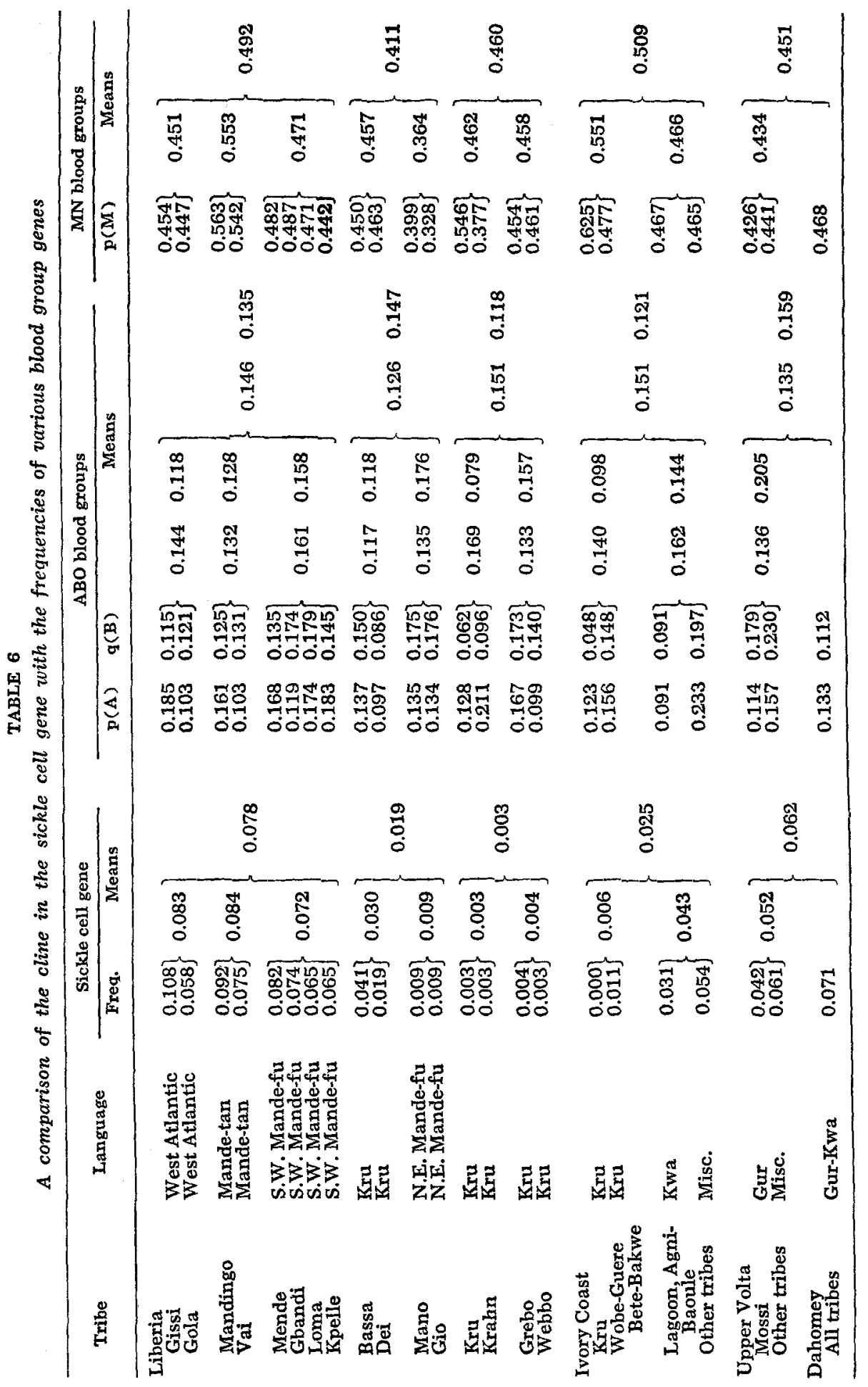




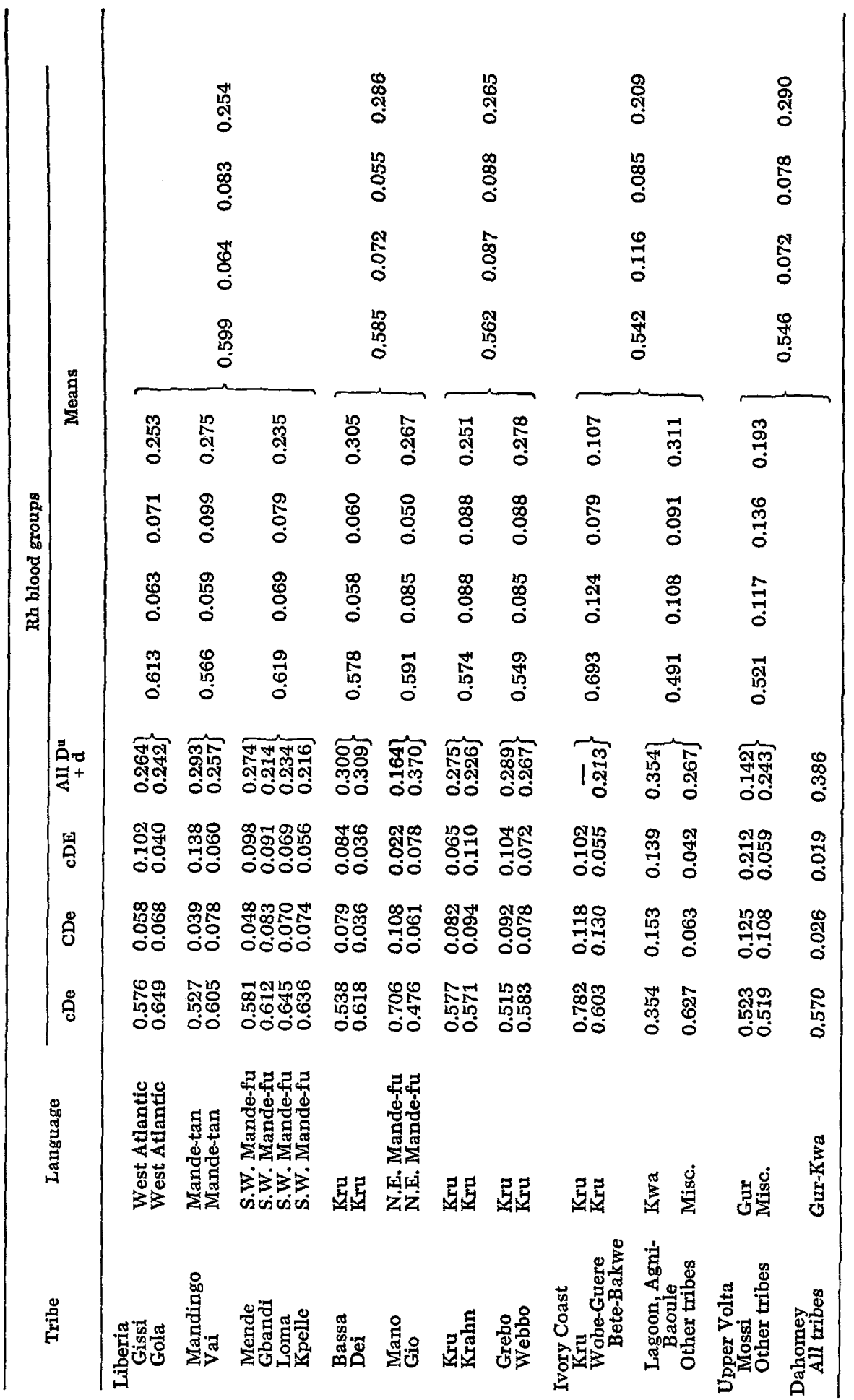


TABLE 7

A comparison of the blood groups and sickle cell gene frequencies among the tribes of Portuguese Guinea ${ }^{1}$

(Numbers in parentheses refer to number of individuals tested)

\begin{tabular}{llllll}
\hline \multicolumn{1}{c}{ Tribe } & $\begin{array}{c}\text { Sickle cell } \\
\text { gene }\end{array}$ & $\begin{array}{c}\text { Blood } \\
\text { group A }\end{array}$ & $\begin{array}{c}\text { Blood } \\
\text { group B }\end{array}$ & $\mathbf{R h}-(\%)$ & Language \\
\hline Baiote & $0.001(342)$ & & & $0.252(126)$ & West Atlantic \\
Mancanhas & $0.001(534)$ & 0.190 & $0.201(56)$ & $0.280(459)$ & West Atlantic \\
Bijago & $0.003(632)$ & 0.185 & $0.150(225)$ & $0.241(258)$ & West Atlantic \\
Balante & $0.005(776)$ & 0.238 & $0.162(58)$ & $0.254(481)$ & West Atlantic \\
Papel & $0.007(1244)$ & 0.170 & $0.116(87)$ & $0.288(410)$ & West Atlantic \\
Manjacos & $0.010(758)$ & 0.172 & $0.124(87)$ & $0.294(427)$ & West Atlantic \\
Felupe & $0.028(641)$ & 0.101 & $0.177(200)$ & $0.234(510)$ & West Atlantic \\
Nalu & $0.030(100)$ & 0.112 & $0.183(200)$ & $0.257(560)$ & West Atlantic \\
Biafada & $0.064(797)$ & 0.144 & $0.137(237)$ & $0.221(470)$ & West Atlantic \\
Pajadinca (Conagui) & $0.080(300)$ & 0.147 & $0.207(203)$ & & West Atlantic \\
Fula Forros & $0.079(2053)$ & 0.167 & $0.157(327)$ & $0.248(408)$ & Fulani (W. Atl.) \\
Fula Futa & $0.087(682)$ & 0.172 & $0.139(200)$ & $0.295(426)$ & Fulani (W. Atl.) \\
Fula Pretos & $0.126(430)$ & & & $0.279(565)$ & Fulani (W. Atl.) \\
Mandingo & $0.058(895)$ & 0.195 & $0.208(94)$ & $0.206(608)$ & Mande \\
Mandingo & $0.075(500)$ & & & & \\
\hline
\end{tabular}

'Data from Leite and Re, '55; Trincao, n.d.; Mourant et al., '58; and Trincao et al., '53.

Urundi and the Belgian Congo there are relatively few populations which seem not to be in or approaching equilibrium for the sickle cell gene, and the major cline in the frequency of this gene seems to be determined by differences in the amount of falciparum malaria which are dependent on altitude. Thus, this appears to be a stable cline in contrast to the cline in Liberia which is not associated with differences in the endemicity of falciparum malaria.

As in Portuguese Guinea and Liberia, the distributions of $\mathrm{Rh}$ and $\mathrm{MN}$ blood group genes in Ruanda-Urundi and the eastern Belgian Congo do not show any associations with the cline in the sickle cell gene. As in Liberia there are some differences, such as the low frequency of $B$ or the high frequency of $M$ among the Tutsi, which seem to reflect ethnic differences, but there is certainly no overall pattern of differences in blood group gene frequencies associated with linguistic or ethnic differences. However, within the Bantu tribes the variability in the $O$ gene is positively correlated with that in the sickle cell gene $(\mathrm{r}=+.75,11$ d.f., $\mathrm{P}<$ 0.01 ), while the $A$ gene is negatively correlated with the sickle cell gene $(r=-.72$, 11 d.f., $P<0.01$ ). It may be that the differences in altitude which have resulted in differences in selection at the sickle cell locus have also influenced the $A B O$ genes. Or it may be that malaria is a selective factor for the $\mathrm{ABO}$ genes and only in Ruanda-Urundi where the sickle cell cline is stable could this correlation be detected.

Despite the fact that no significant clines were observed in West Africa for the major blood group genes, in contrast to the findings for the sickle cell gene, it should not be lost sight of that the tribes of West Africa differ significantly in the frequency of some blood group genes. These differences seem to be the result of genetic drift or of selective response to local, unidentified factors and not associated with common ancestry, way of life, or region which the tribe inhabits. Since there is increasing evidence that the gene frequencies of many blood group systems are maintained by a balanced polymorphism, the similarity of blood group frequencies throughout Africa implies that the selective forces maintaining these balanced polymorphisms are relatively constant throughout this region. Whatever these forces are, it is noteworthy that the great changes which resulted from the adoption of an agricultural economy by hunting populations and which are responsible for the spread of falciparum malaria and the sickle cell gene have 
not affected them. In addition to the primitive "relict" populations in Portuguese Guinea and Liberia the Pygmies and Bushmen have frequencies of the blood group genes which are similar to those of the surrounding Bantus. Since the transition to an agricultural economy results in changes in the diseases prevalent among the population (Hare, '55), the absence of marked differences in the frequencies of the blood group genes between agricultural and hunting populations in Africa seems to imply that these diseases are not involved in the selective forces maintaining the blood group gene frequencies. However, since it seems most likely that a great many diseases are involved in these selective forces, an alternative explanation is that the equilibrium frequencies are the same in both a primitive hunting population and in an agricultural population but are maintained by quite different kinds of selection.

We turn now to consider briefly evidence for clines in the "minor" blood groups and the haptoglobin system. Evidence for the existence of a cline in the haptoglobin gene similar to that for the sickle cell gene has already been reported (Sutton et al., '59). Since intermediate frequencies of the haptoglobin alleles are found in many populations, these frequencies appear to be maintained by a balanced polymorphism. Hence the great changes in the disease environment which are associated with the increase in the frequency of the sickle cell gene also seem to be associated with an increase in the frequency of the $\mathrm{Hp}^{1}$ allele. Since the haptoglobin associated with this allele seems to be more efficient in binding hemoglobin and thus in preventing loss of hemoglobin via the renal system, and since a hemolytic anemia is a common finding in malaria because of the destruction of the red cells by the parasite, malaria could also be an important selective factor in increasing the frequency of this allele. There is no evidence for non-uniform distribution of the $\mathrm{Fy}^{\mathrm{a}}, \mathrm{K}, \mathrm{P}$, and $\mathrm{Tj}^{\mathrm{a}}$ or $\mathrm{Di}^{\mathrm{a}}$ antigens in the regions covered by these studies. With respect to the possible cline in the genes responsible for the $\mathrm{He}$ and $\mathrm{U}$ antigens noted above, the data are not clear as to how well these clines correlate with the sickle cell cline-further data on this point are to be desired. Finally, we record an apparent high for $\mathrm{Jk}^{\mathrm{a}}$ negatives in the regions studied, but no evidence for a cline.

One further aspect of our findings which finds confirmation in a number of other studies is the difference in variability of the major blood group systems. It is usual to find the variability much greater among the ABO blood groups than the Rh blood groups, and the variability in the MN system is usually intermediate. This increased variability in the $A B O$ system is usually associated with the A gene (Ruffié, '58; Mourant, '59; Hiernaux, '55). Since among a set of populations the role of gene drift and gene flow in determining gene frequencies would be the same for all genetic systems-assuming a similar antiquity for the systems involved-this increased variability seems to be due to differences in the selective forces which are operating on the different blood group systems. Whether this implies that there is stronger selection for the ABO system as Mourant ('59) has conjectured, or whether it implies that the $A B O$ system is more subject to gene drift and hence that selective pressures are less, has yet to be determined. In any case, the unravelling of the factors which can influence gene frequencies and which are responsible for these differences in the variability of the blood group systems is one of the major problems facing human population genetics and physical anthropology today.

\section{SUMMARY}

Data are presented on the distribution of the ABO, MN, Rh, Fy ${ }^{\mathrm{a}}, \mathrm{K}, \mathrm{U}, \mathrm{P}, \mathrm{Jk}^{\mathrm{a}}, \mathrm{Tj}^{\mathrm{a}}$, $\mathrm{He}$, and $\mathrm{Di}^{\mathrm{a}}$ blood groups in Liberia, the Ivory Coast, and Upper Volta. An attempt was made to determine whether there were clines in the frequency of the genes responsible for these groups comparable to the clines in the frequency of the sickle cell gene already demonstrated in this region. Such clines appear to be absent, with the possible exception of the $\mathrm{He}$ and $\mathrm{U}$ blood groups, and-at an even lower level of probability-the $\mathrm{Jk}^{\mathrm{a}}$ group. The significance of these findings is discussed. 


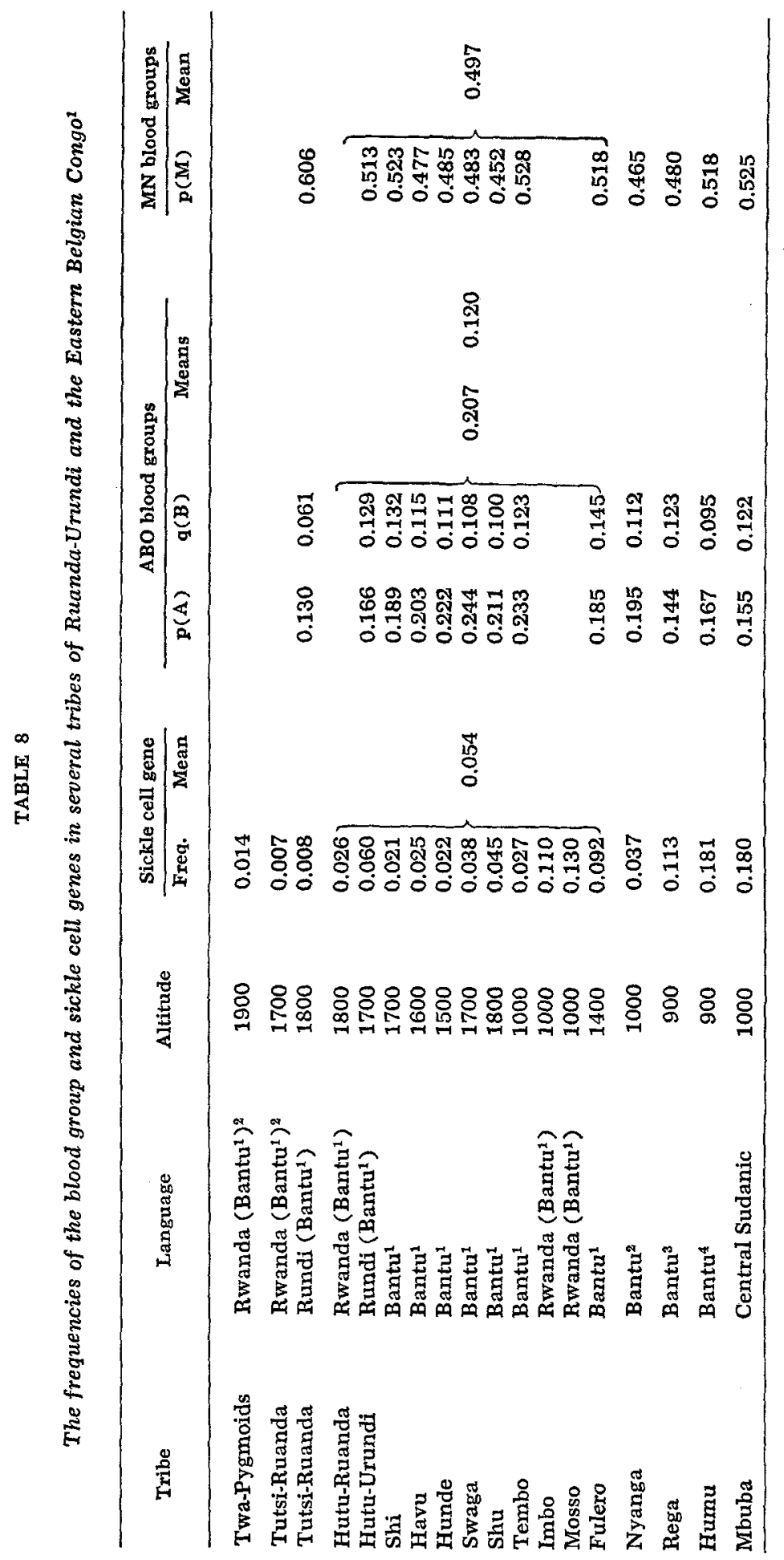




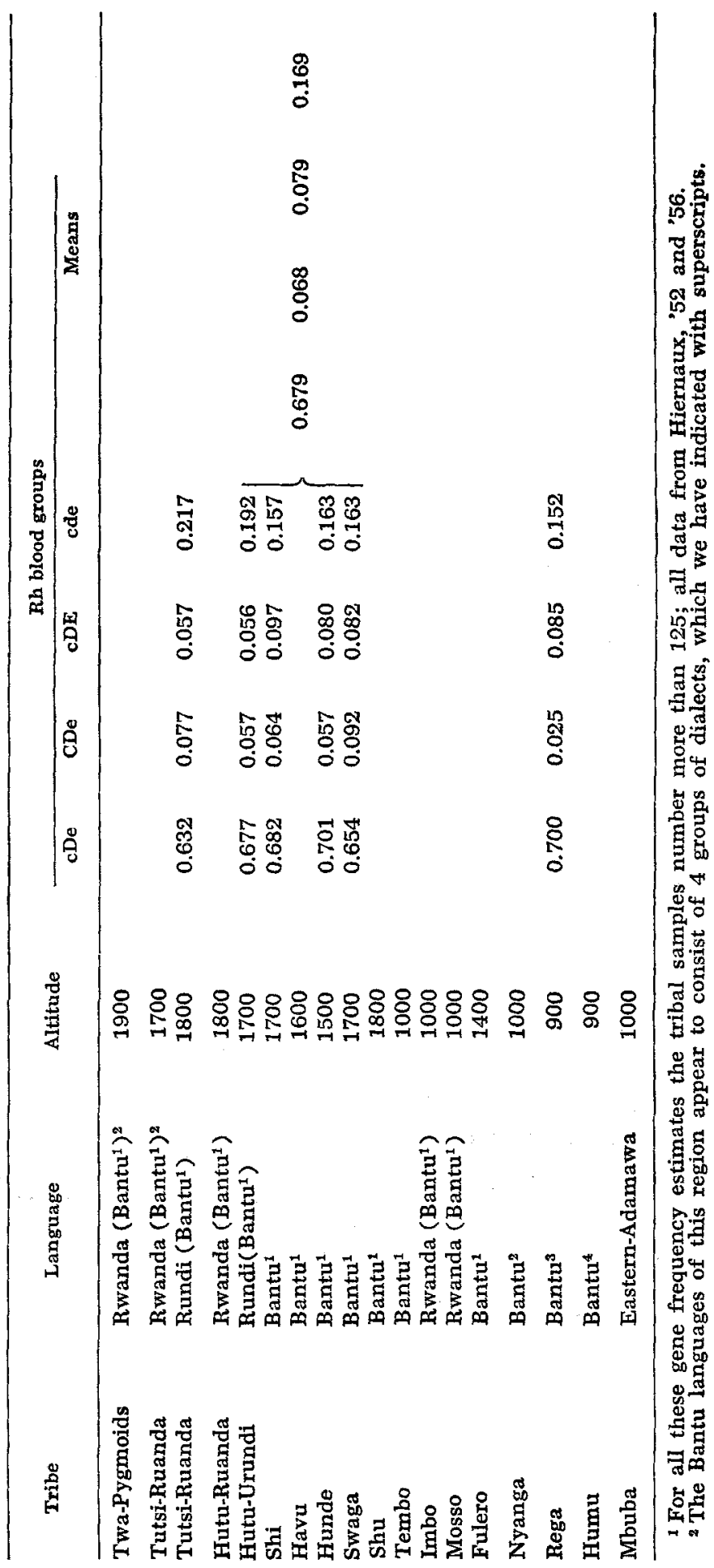




\section{LITERATURE CITED}

Gershowitz, H. 1959 The Diego factor among Asiatic Indians, Apaches, and West African Negroes; blood types of Asiatic Indians and Apaches. Am. J. Phys. Anthrop., 17: 195-199.

Glass, H. B. 1955 On the unlikelihood of significant admixture of genes from the North American Indians in the present composition of the Negroes of the United States. Am. J. Human Genet., 7: 368-385.

Glass, H. B., and C. C. Li 1953 The dynamics of racial intermixture-an analysis based on the American Negro. Ibid., 5: 1-20.

Hare, R. 1955 Pomp and Pestilence. Philosophical Library, New York.

Hiernaux, J. 1952 La gènetique de la Sicklémie et l'interet anthropologique de sa frequence en Afrique noire. Ann. Musée Royal Congo Belge, Tervuren, vol. 2.

1955 Physical anthropology and the frequency of genes with a selective value: the sickle cell gene. Am. J. Phys. Anthrop., 13: 455-472.

- 1956 Analyse de la variation des caractères physiques humains en une région de l'Afrique centrale: Ruanda-Urundi et Kivu. Ann. Musée Royal Congo Belge, Tervuren, vol. 3.

Julien, P. 1937 Die blutgruppenverteilung bei einigen Volkern von Liberia und Sierra Leone, Westafrika (mit 7 Abbildungen). Ztschr. Rassenphysiol., 9: 146-159.

Lambotte-Legrand, J. et C. 1958 Notes complémentaires sur la drepanocytose I. Sicklémie et malaria. Ann. Soc. Belge Med. Trop., 38: 45-54.

Leite, A. S., and L. Re 1955 Contribution a l'étude ethnologique des populations africaines. Arch. Inst. Pasteur d'Algerie, 33: 344-349.

Livingstone, F. B. 1958a The distribution of the sickle cell gene in Liberia. Am. J. Human Genet., 10: 33-41.

- 1958b Anthropological implications of sickle cell gene distribution in West Africa. Am. Anthrop., 60: 533-562.

Miller, E. B., R. E. Rosenfield and P. Vogel 1951 On the incidence of some of the new blood agglutinogens in Chinese and Negroes. Am. J. Phys. Anthrop., 9: 115-126.

Moullec, J., J. Linhard and E. Sutton 1952 Quelques données sur les groupes sanguins des populations d'Afrique Occidentale Francaise. Rev. Hematologie, 7: 513-518.

Mourant, A. E. 1954 The Distribution of the Human Blood Groups. C. C Thomas, Springfield.

Brit. Med. Bull., 15: 140-144.
Mourant, A. E., A. C. Kopec and K. DomaniewskaSobczak 1958 The ABO Blood Groups. Blackwell Sci. Pub., Oxford.

Nijenhuis, L. E. 1955 The Henshaw blood group ( $\mathrm{He}$ ) in Papuans and Congo Negroes. Vox Sanguinis, 3: 112-114.

Osborne, R. H. 1958 Serology in physical anthropology: technical problems as revealed by repeated blood determinations in twins. Am. J. Phys. Anthrop., 16: 187-196.

Pollitzer, W. S. 1958 The Negroes of Charleston (S. C.); a study of hemoglobin types, serology and morphology. Ibid., 16: 241-264.

Race, R. R., and R. Sanger Blood Groups in Man. Blackwell Sci. Pub., Oxford.

Raper, A. B. 1956 Sickling in relation to morbidity from malaria and other diseases. Brit. Med. J., 1: 965-966.

Ruffie, J. 1958 Etude sero-anthropologiques des populations autochtones du versant nord des Pyrenees. Bull. Mem. Soc. Anth. Paris, 19: 3-91.

Sanger, R., R. R. Race and J. Jack 1955 The Duffy blood groups of New York Negroes: the phenotype Fy (a-b-). Brit. J. Haematol., 1: 370-374.

Shapiro, M., and J. M. Vandepitte 1955 Blood groups and sickle cell trait in Congo Bantu. Reports and Communications of the Vth International Congress of Blood Transfusion, pp. 243-246.

Sutton, H. E., J. V. Neel, F. B. Livingstone, G. Binson, P. Kunstader and L. E. Trombley 1959 The frequencies of haptoglobin types in five populations. Ann. Human Genet., 23: 175-183.

Trincao, C. 1958 Results of a paper electrophoresis survey of the tribes of Portuguese Guinea. Presented at Sixth International Congress of Tropical Medicine and Malaria. Lisbon.

Trincao, C., A. Franco, E. Gouveia and F. Parreira 1953 O factor sanguineo $\mathrm{Rh}_{\mathrm{o}}$ (D) nas principais tribos da Guine Portuguesa. An. Inst. Med. Trop., 10: 197-199.

Vandepitte, J., and J. DeLaisse 1957 Sicklémie et paludisme. Ann. Soc. Belge Med. Trop., 37: 703-736.

Wahlund, S. 1928 Zusammensetzung von Populationen und Korrelationserscheinungen von Standpunkt der Vererbungslehre aus betrachet. Hereditas, 11: 65-106.

Wiener, A. S., L. J. Unger and E. B. Gordon 1954 Fatal hemolytic transfusion reaction caused by sensitization to a new blood factor U. J. Am. Med. Assoc., 153: 1444-1446.

Zoutendyk, A. 1955 The blood groups of South African natives with particular reference to a recent investigation of the Hottentots. Reports and Communications of the Vth International Congress of Blood Transfusion, pp. 247-249. 